\title{
The lahars of the South-East slope of Mount Cameroon: geological study, economic interest and impacts of their exploitation on the environment
}

\author{
Joseph Legrand Tchop ${ }^{*}{ }^{\oplus}$, Victor Metang ${ }^{2}{ }^{\circ}$, Jacques Dili-Rake ${ }^{1}{ }^{\circ}$, Gaelle Vanessa Nana ${ }^{\circledR}$, Pauline \\ Wokwenmendam Nguet $1{ }^{1}$, Bernard Tassongwa ${ }^{3 \oplus}{ }^{\circledR}$, Benjamin Ntieche 4
}

${ }_{1}^{1}$ Institute of Geological and Mining Research, Geophysical and Volcanological Research Unit, Buea, Cameroon

${ }^{2}$ University of Yaoundé 1, Faculty of Sciences, Department of Earth Sciences, Yaoundé, Cameroon

${ }^{3}$ University of Dschang, Faculty of Sciences, Department of Earth Sciences, Dschang, Cameroon

${ }^{4}$ University of Yaoundé 1, Higher Teacher Training College, Yaoundé, Cameroon

\section{Keywords}

Mount Cameroun

Explosive eruption

Lahars

\begin{abstract}
Mount Cameroon is the site of explosive eruptions with the emission of ash, slag and lava flows. Mudflows, known as Lahars, can also be observed. These Lahars are mainly found in the lower part of the south-eastern slope. The outcrops observed on this flank show that these Lahars are very extensive and are avalanches of volcanic material, which flowed down the slopes of the volcano after the eruptions. The different outcrops observed are separated by pyroclastic products on which the lahars rest. The components of these lahars are generally black or grey basalts. The main granulometric characteristic of the deposits of these lahars is their heterometry. The size of the material varies from a few meters to the clay fraction. Large concentrations of mineable material are found in the watercourses. These materials are exploited in order to produce aggregates for civil engineering. This exploitation has consequences on the immediate environment. In addition to climatic factors, several parameters have influenced the mobilities and emplacement of the lahars on the south-eastern slope of Mount Cameroon: the slope, the volume and thickness of the deposits, the nature and physico-hydric characteristics of the deposits. The persistence of strombolian volcanic eruptions on Mount Cameroon and the particularly rainy context predispose it to other future episodes of lahar flow.
\end{abstract}

\section{INTRODUCTION}

In all geodynamic contexts, the magmas that reach the earth's surface generate volcanism. And the products (flows, fall out, projections, domes, etc.) accumulate in various ways. The volcanism can generate superficial phenomena such as landslides, mudflows or lahars and others (Dionne, 1991).

The term lahar, of Indonesian origin, refers to a mixture of water and debris of volcanic origin that collapse at high speed over a volcano and its foothills (Lavigne and Thouret, 2000; Huguet et al., 2001; Smith and Fritz, 1989). The phenomenon remobilizes ashes and blocks that have fallen on a volcano flank as a result of instability such as earthquakes, landslides and meteoric causes (Lavigne et al., 2000).

Mount Cameroon (Figure 1) is the highest volcanic massif in Central and West Africa $(4095 \mathrm{~m})$ in the intra plate continental domain characterized by alkaline volcanism (Déruelle and Kambou, 1987). Explosive eruptions emitted ash, slag and fluid lava flows. Besides these pyroclastic materials and lava flows, there are landslides (Lambi and Ngawana, 1991; Ayonghe et al., 2002; Ayonghe et al., 2004; Tytgat Nele, 2008) which are mudflows and intermingled rocks such as lahars (Figure 1). Lahars mostly outcrop in the lower zone of the south eastern flank in various localities Buea, Likomba, Ombe, Mutengene, Dibanda, Ekona and Bwenga.

\section{* Corresponding Author}

Cite this article 
No detailed study has yet been carried out on these lahars though their exploitation for years for various uses. This exploitation is generally easy because of their great geotechnical qualities (Tchungouelieu et al., 2018).

The geological and geomorphological context of setting of lahars is mostly explained by the combination of internal geodynamic (mainly explosive strato-volcanoes) and external (meteorological, hydrological) factors (Lavigne and Thouret, 2000). Volcanoes located in tropical zones (prone to heavy and brutal precipitation) and glaciated volcanoes (Andes Cordillera) are the most concerned (Fisher and Schemincke, 1984; Rodolfo and Arguden, 1991; Thouret et al., 1995; Thouret et al., 1998; Corwin et al., 2017).

Most studies on Mount Cameroon focus on petrology, geochemistry (N'ni, 1984; Déruelle et al., 1987; Nkoumbou et al., 2001; Suh et al., 2003; Ngounouno et al., 2006; Tsafack et al., 2009; Wandji et al., 2009; Ngwa et al., 2019), seismology (Ateba and Ntepe, 1997; Ateba et al., 2009), volcanism (Bardintzeff et al., 2000) and natural hazards such as landslides (Lambi and Ngawana, 1991; Ayonghe et al., 2002; Ayonghe et al., 2004; Tytgat Nele, 2008; Kervyn et al., 2014). Lahars on this south-eastern slope of the volcano have not been thoroughly studied, the reason of their current geological, geomorphological and economic interest.

Moreover, the site is one of the wettest areas in the world (Tsalefack et al., 2003) and Mount Cameroon is still an active volcano indicating that the lahar phenomenon is still pending. Thus, a geological study on Mount Cameroon lahars becomes a necessity.

They three main objectives in this study are:

- The setting mechanism, morphology, petrography and petrology;

- The guide for the prospecting of mineral materials;

- Identifying the environmental impacts of lahar expansion.

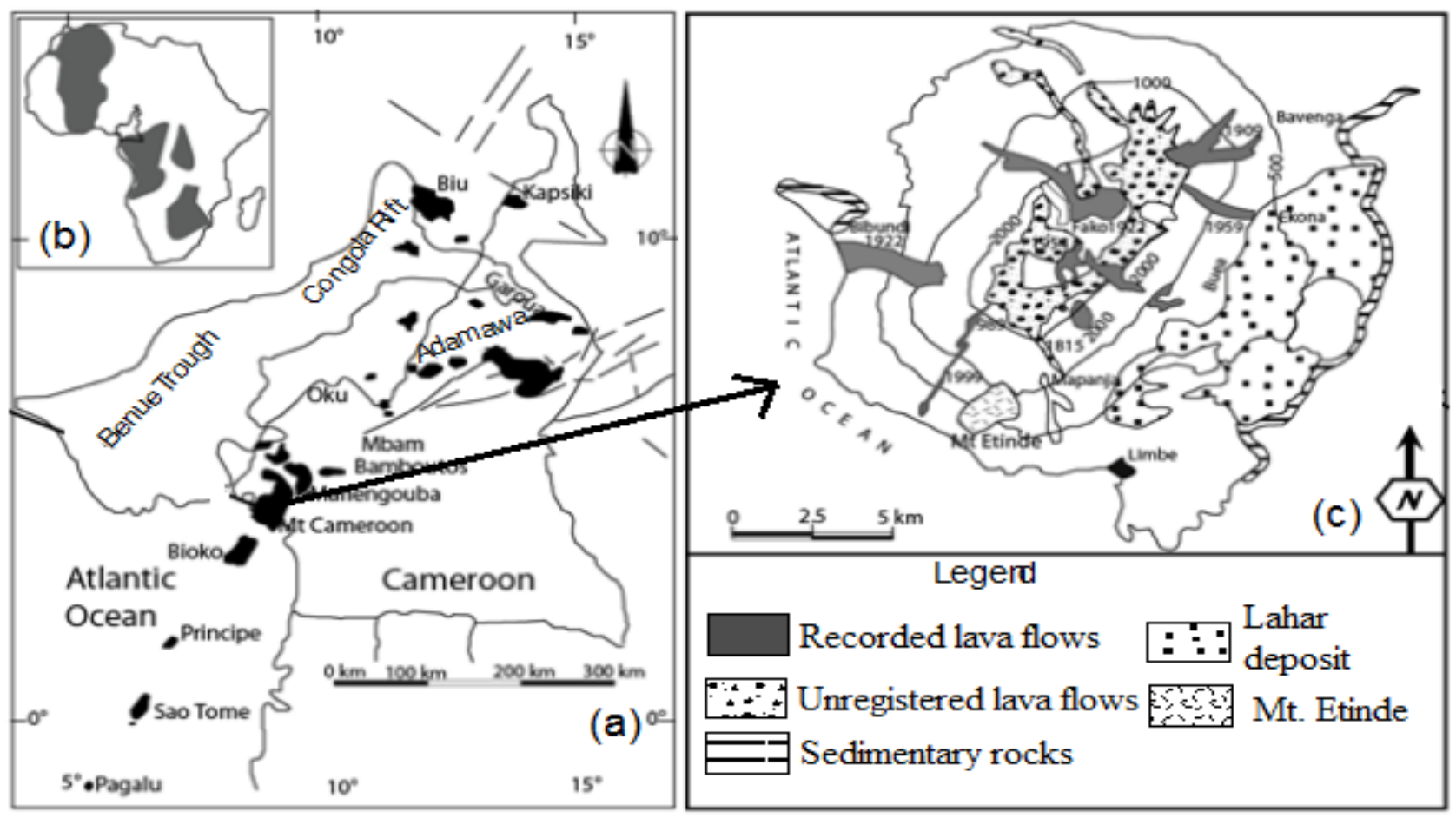

Figure 1. Location of the study area: (a) The Cameroon Volcanic Line; (b) Cratons after Deruelle et al. 1991 and (c) Location of Lahars on the South-East slope of Mount Cameroon

\section{GEOLOGICAL SETTING}

The Cameroon Volcanic Line, on which Mount Cameroon stands, is a volcano-tectonic megastructure oriented $\mathrm{N} 30^{\circ} \mathrm{E}$. It is one of the large intra-plate alkaline volcanic provinces, extending in the oceanic and continental domains (Fitton, 1987; Kagou Dongmo et al., 2001). It is an alignment of oceanic and continental volcanoes of Tertiary to present, from the volcanic island of Pagalu (Figure 1) in the Atlantic Ocean to Lake Chad (Déruelle et al., 1991). The most recent eruptions at Mount
Cameroon took place on 28 March-22 April 1999 and 28 May-19 June 2000 (Suh et al., 2003).

Morphologically, Mount Cameroon is a stratovolcano, located on a horst demarcated by faults expressed by slope breaks (Déruelle, 1982). The products issued are generally represented by Basaltic lavas and their pyroclastic products. Ngounouno et al. (2006) also described Camptonites, a type of lamprophyres made up of plagioclase and brown hornblende. In addition, enclaves (1-5 cm x 0.5-4 cm) of dunites, wehrlites and clinopyroxenites were found in basanites at Batoke in a Strombolian cone (Wandji et al., 2009). 
Enclaves of wehrlites and clinopyroxenites were also found in basaltic tephras in a Strombolian cone (Deruelle et al., 2001).

From the fluidity of the magma, gas pressure and granulometry, there are ashes, bombs, slag, pumice, lapilli and blocks at Mount Cameroon.

\section{METHODOLOGY}

\subsection{Fieldwork}

Fieldwork is an essential step in any good geological study. Several field work enabled us to carry out macroscopic petrographic studies and make direct observations of lahar outcrops. They consist of:

1. Locating the different outcrops with a GPS and topographic maps;

2. Listing and describing the different types of formations observed;

3. Collecting samples for Thin section and granulometric analysis.

\subsection{Laboratory Work}

Thin sections on lavas and slags were made for petrographic study under the microscope. The granulometric analysis on lahars was carried out to assess the frequency of elements. The method used is the sieve size analysis. It consists of washing with water, using a $63 \mu$ sieve, $200 \mathrm{~g}$ of sample. The refusal is dried in an oven at $105^{\circ} \mathrm{C}$ for 24 hours, then weighed and sieved with a successive series of sieves of the AFNOR standard arranged from bottom to top (according to the dimensions of the square mesh): $63 \mu, 125 \mu, 160 \mu, 500 \mu, 1 \mathrm{~mm}, 2 \mathrm{~mm}$, $3 \mathrm{~mm}$. The refusal of each sieve is weighed with a precision balance. Sieve analysis curves were made. Clay fraction was removed during washing.

\section{RESULTS}

\subsection{Geological Characteristics of Lahars} Likomba.

They outcrop at Mutengene, Ombe and

Mount Cameroon lahars are avalanches of volcanic material in large volumes that tumbled down the slopes after the eruptions. They look like conglomerates covering a large area (about $15 \times 20$ $\mathrm{km}^{2}$, Figure 2 and 3). In the lower, gently sloping parts are volcanic cones still in the midst of lahar materials (Figure 4). Pyroclastic products separate different lahar outcrops. At places, there is a very thick pedological cover on pyroclastic products. These lahars are described according to their location, mode of outcropping and lithology.

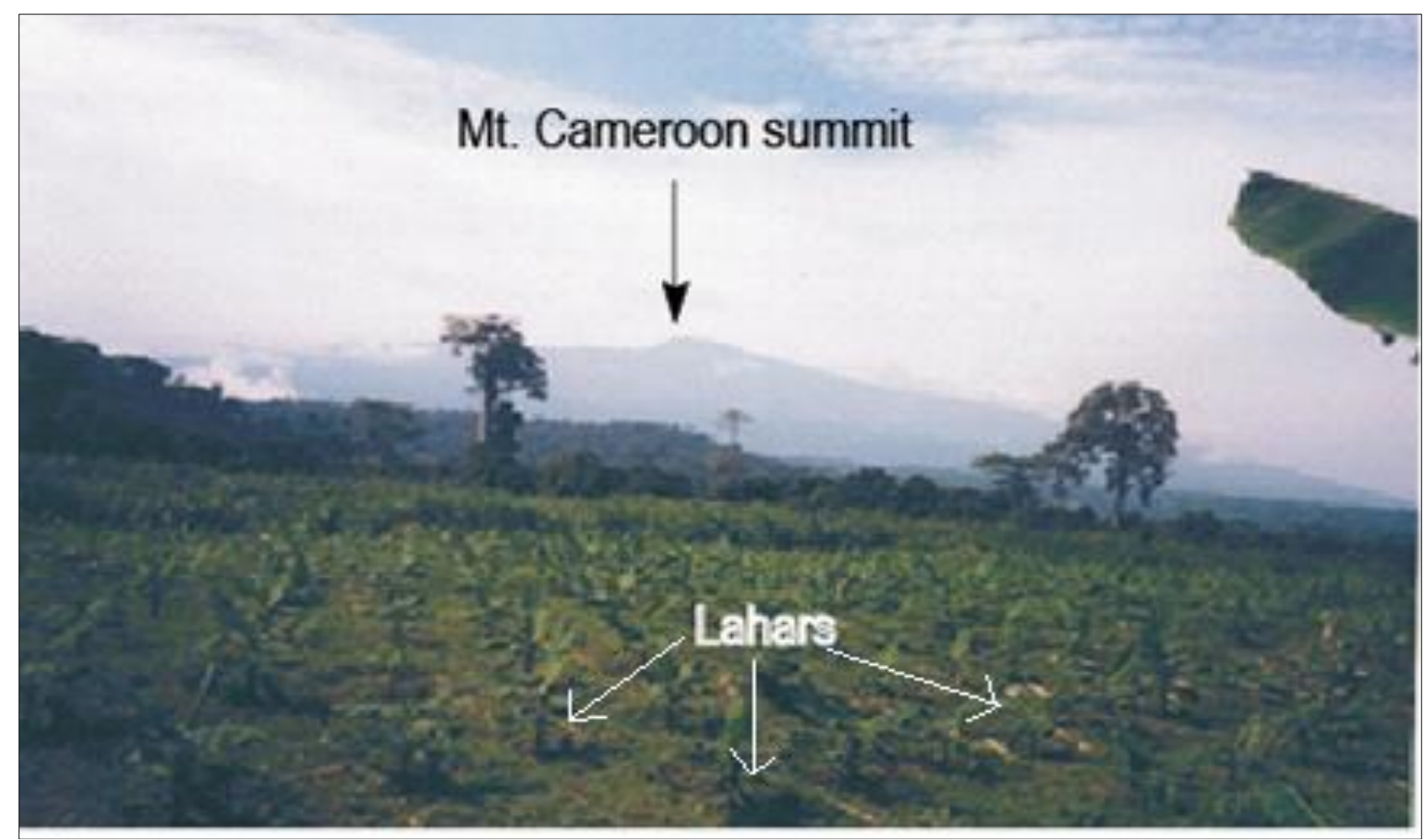

Figure 2. Extension of lahars flow, from the southern limit (Ombe) to the source (Mount Cameroon) 


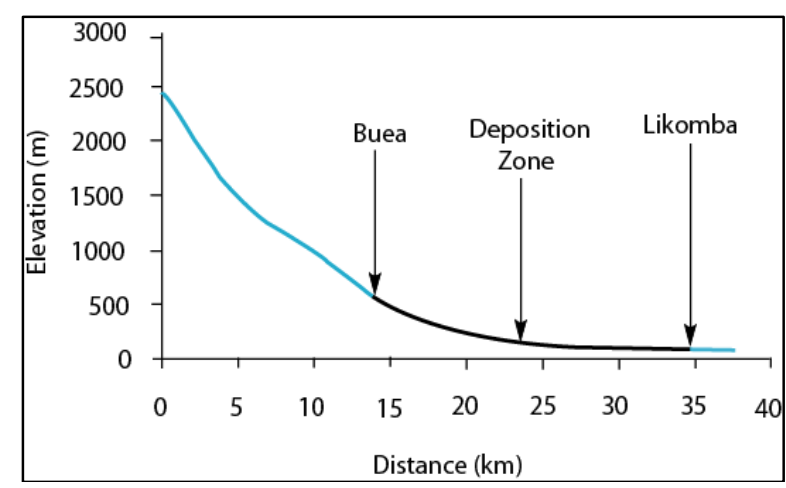

Figure 3. Longitudinal profile from the Mount Cameroon summit to downstream in the Tiko plain (Likomba)

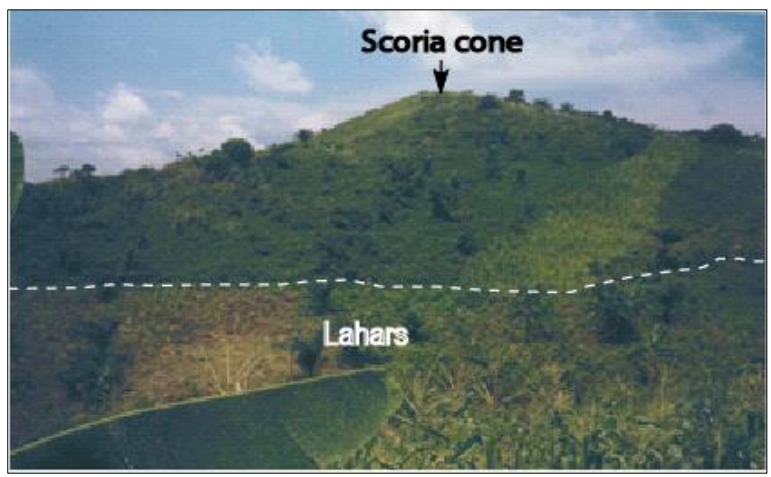

Figure 4. Photograph of the scoria cones emerging in the middle of lahars

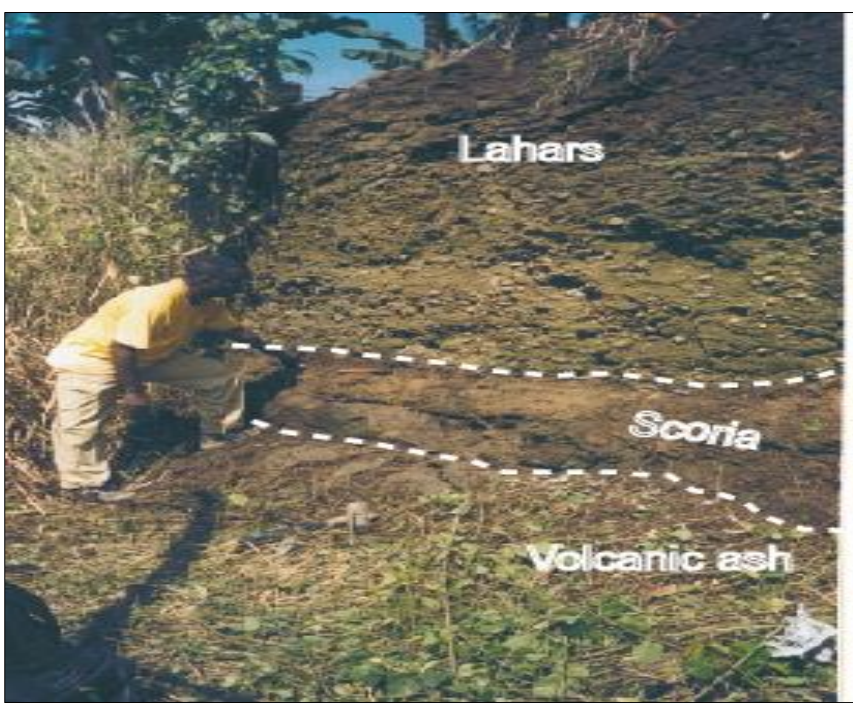

\subsubsection{Ombe outcrops}

Lahar outcrops observed along the Ombe River extend continuously as far as Ombe-Native, almost $9 \mathrm{~km}$ south of Mutengene. They look like conglomerates in blocks of various sizes agglomerated by a sandstone matrix and covered by vegetation consisting of agro-industrial plantations of banana and palm trees. The topography at Ombe is relatively flat; but in detail, it presents interfluves and depressions where lahars partially mold hills of pyroclastic rocks (slag and ash, Figure 4). At road trenches and in incised valleys, the structures of lahars are maintained, with blocks well distributed.

Ombe River lahars; Lahars occupy most the river bed with generally identical elements and in descending order of importance, rounded blocks and pebbles.

-Rounded blocks of different sizes (from centimeters to several meters) witnessing a long transport. Their proportion reaches 80 to $90 \%$ in most places.

-Oval or flattened pebbles $(\leq 3 \mathrm{~cm}$ in size $)$ interspersed with gravel, sand and mud.

The Ombe River flows at the western limit of lahar deposits bear large boulders at bends and meanders. On its banks large slag slopes form the bedrock of lahars. These slags are friable or compact, about $8 \mathrm{~m}$ height (Figure 5).

Figure 5. Contact between lahar blocks and the substratum (ash and slag) at its southern limit

\subsubsection{Morphology of Tiko-Mutengene lahars}

Tiko-Mutengene lahars offer a stepped topography comprising the Tiko unit (about 30m altitude), the Likomba unit (about 60m) and the Mutengene unit $(150 \mathrm{~m})$. They mostly outcrop along rivers (Figure 8a) such as Essuke, Ndongo and Benoe. These lahars are strips several kilometers long, hundreds meters wide and 15 to 90 meters high. The vegetation is important.

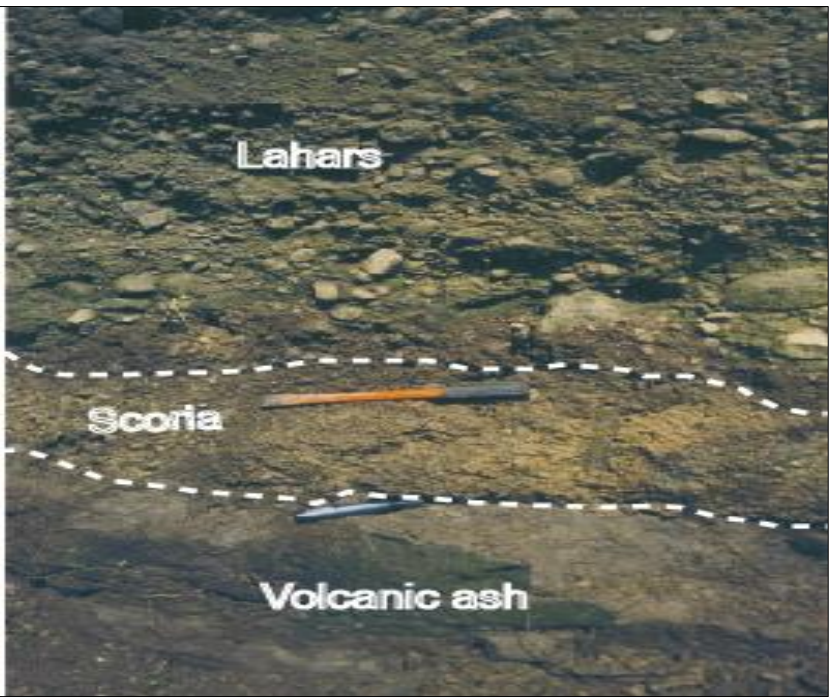

These lahars generally present the same textural and lithological features, but with the proportions of elements varying from one outcrop to another (Figure 6 and 7). In general, large blocks abound. At road trenches, lahars are heterogeneous and massive, conglomeratic; with different size blocks in sandstone cement (Figure 8c). 


\subsubsection{Morphology of Tamben-Dibanda lahars}

Tamben-Dibanda lahars outcrop to the north of Mutengene and stretch on slopes for more than 15 $\mathrm{km}$ right to mile 17 Buea. Blocks are light grey in color, larger ( $50 \mathrm{~cm}$ to $\geq 2 \mathrm{~m}$ in diameter) but smaller in size at mile 17 (10 to $40 \mathrm{~cm}$ in diameter). Vesicular blocks abound with millimeters to centimeters vacuoles.

\subsubsection{Morphology of Bwenga lahars}

Bwenga lahars outcrop in small blocks $(\leq 30$ $\mathrm{cm}$ ) at the south-eastern end of all the studied lahars in a vast plain on stratified ashes. Textural and lithological features are similar to the others but with blocks lesser in size (Figure 8a).

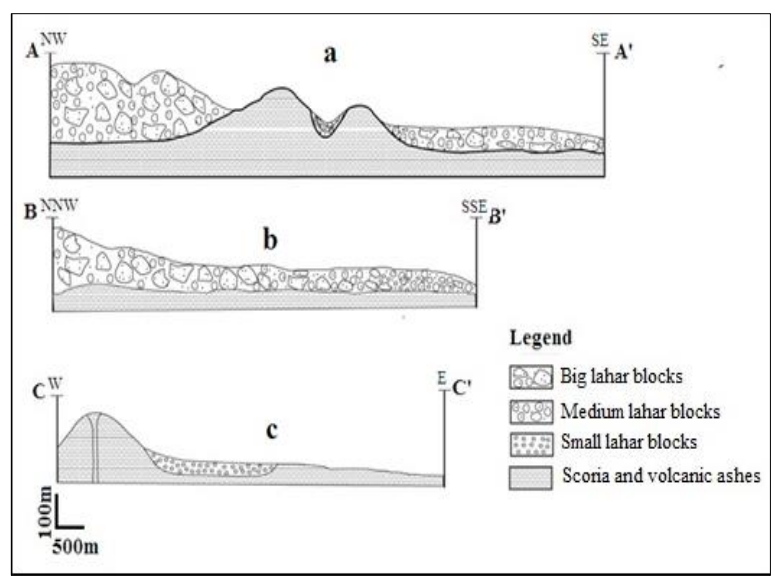

Figure 6. Geological profile showing the lateral and vertical structure of lahars

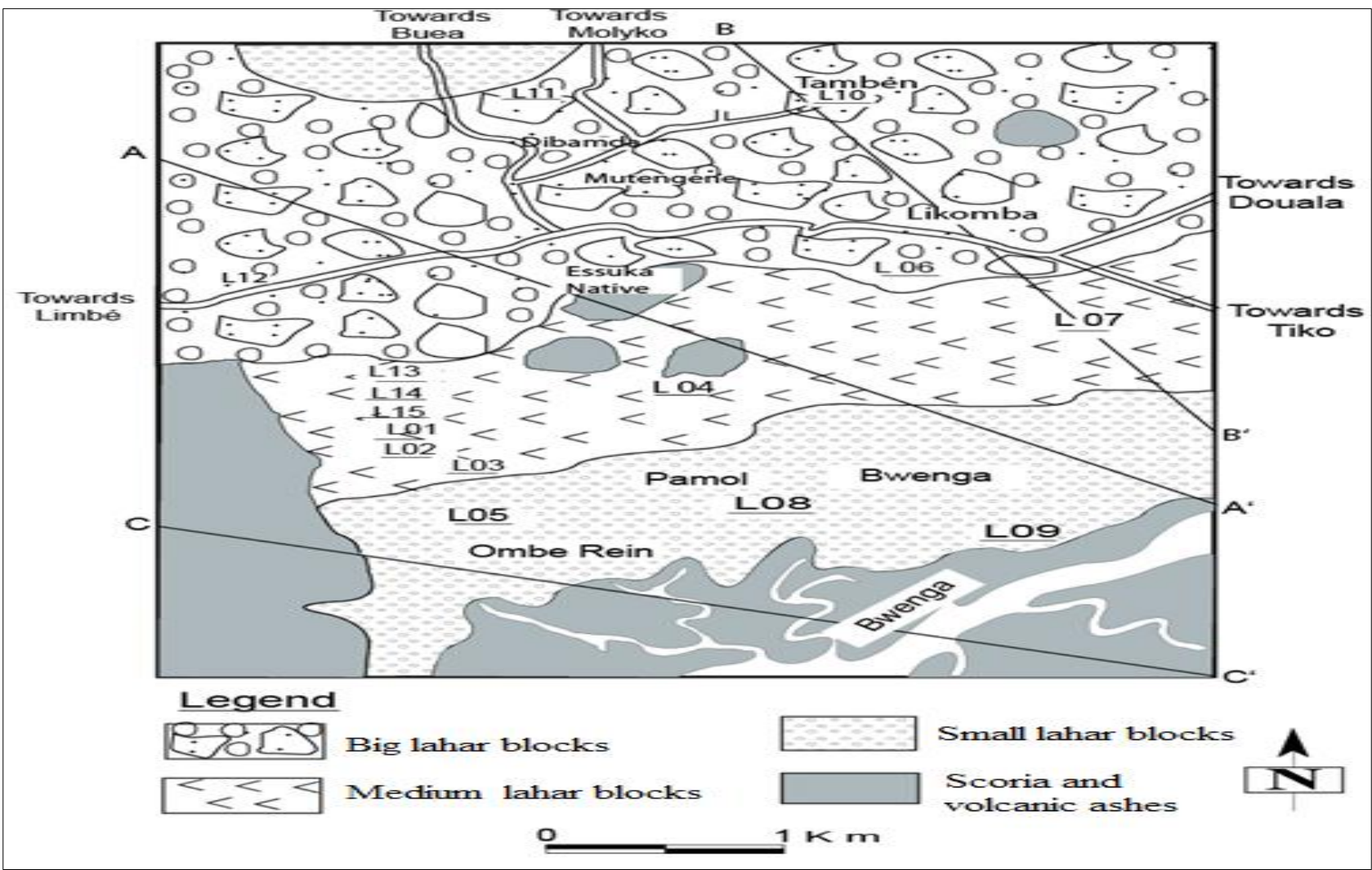

Figure 7. Map of lahar outcrops on the south-eastern flank of Mount Cameroon

\subsection{Petrography}

On the southeastern slope of Mount Cameroon lahars are basalts generally black or grey in color, compact or vesicular (Figure 8b). Vacuoles are rounded or elongated in the same direction. Blocks range from a few centimeters to a few meters (Figure 8a and 8b). The microscopic study reveals an aphyric microlitic or porphyritic microlitic texture with olivine, pyroxene and / or plagioclase phenocrysts (Figure 9).

Porphyritic basalts are rich in olivine phenocrysts (3-7 $\mathrm{mm})$, pyroxene and plagioclase (10-25\%) euhedral to subeuhedral, scattered or clustered. Olivine and pyroxene abound. Sub- aphyric basalts show smaller size phenocrysts, below $2 \mathrm{~mm}$. Aphyric basalts are finely crystallized with black or grey paste and no mineral is discernable to the naked eye (Figure 9a). Vacuolar blocks show almost the same features: less dense, spongy, very fine or developed vacuoles (rounded or elongated) with sizes up to several centimeters. Phenocrysts of olivine and/or pyroxene are present in some samples (Figure 9b).

Petrographic features of blocks in the studied lahars are identical in all the lavas resulting probably from various eruptions of Cameroun Mount; their elements result from several eruptions. 

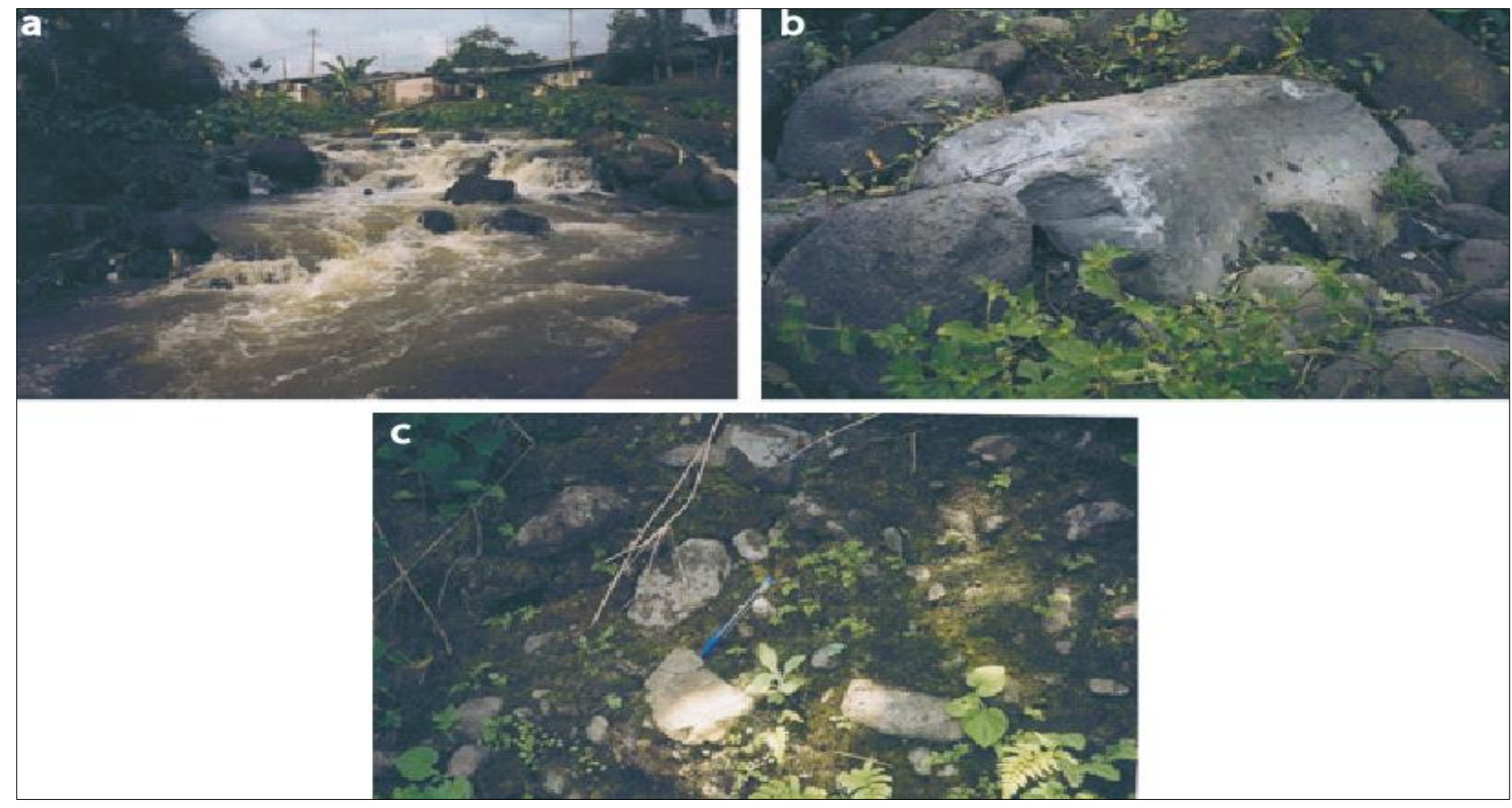

Figure 8. a) Metric blocks in the Benoe River (Mutengene); b) Porphyritic or aphyric blocks; c) Conglomeratic lahars (Mutengene-Ombe road)
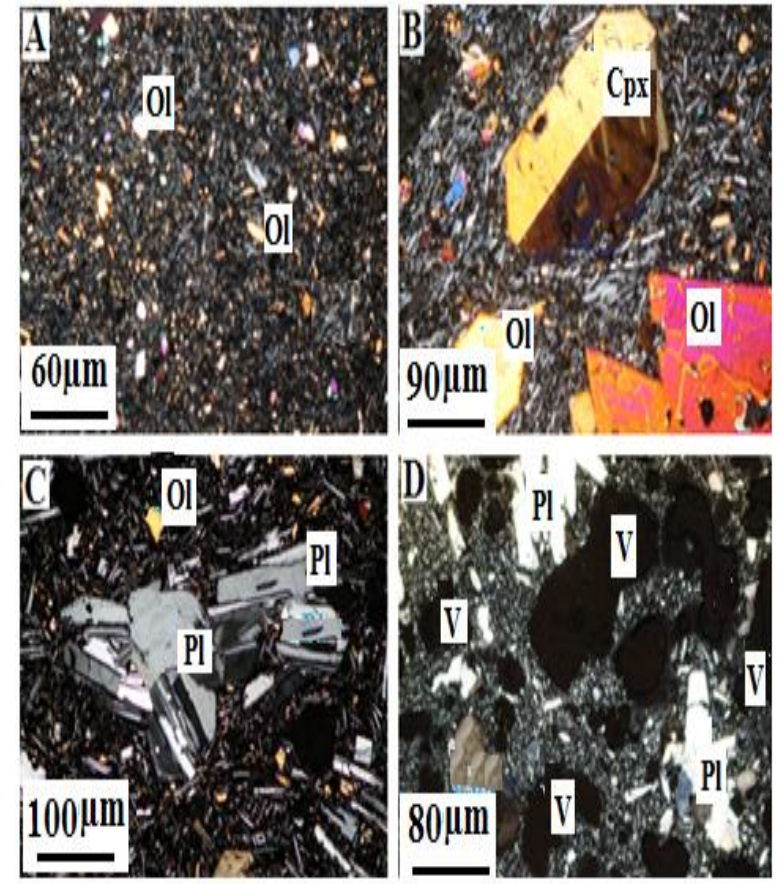

Figure 9. Textures of basalts on the SE slope of Mount Cameroon. A: Aphyric; B: Porphyric; C: Microlitic with trachytic tendency; D: Vesicular. (Ol=Olivine; $\mathrm{Cpx}=$ clinopyroxene; $\mathrm{Pl}=$ plagioclase; $\mathrm{V}=$ Vesicula; according to Kretz, 1983)

\subsection{Granulometric Analysis of the Fine Lahars}

\subsubsection{Elements size distribution}

The elements in the studied lahars vary from clays to blocks and from one deposit to another (Figure 10). Heterometry is their main feature with rounded to sub-angular and very poorly sorted elements, compared with pyroclastic deposits beneath. Their deposition process conforms to the progressive aggregation model illustrated at Mont Rainier (Vallance and Scott, 1997).

\subsubsection{Granulometric analysis}

The particle size analysis concerns only fractions below $5 \mathrm{~mm}$. It was carried out to determine the greater or lesser frequency of elements of different dimensions. The size of the materials varies from a few meters to clay fraction. Thus, the materials are poorly sorted. Tables 1, 2 and 3 show the concentration of fragments and clay. Moreover, the deposits are poly lithological, with mixed pyroclastic materials, lava and fragments from banks or the channel bed. The matrix is mainly sandy-gravel (Figure 11) (Scott et al., 1995). 
Table 1. Particle size analysis results (Sample L13, Lithology: Lahar, Location OMBE, Fraction<63 $\mu$ : 28.69, Dry start weight: 200g, Final dry weight: 171.31g)

\begin{tabular}{|l|l|l|l|l|}
\hline Mesh size of sieves (mm) & Partial refusals (g) & Cumulative refusals (g) & Partial percentages (\%) & $\begin{array}{l}\text { Cumulative percentages } \\
(\%)\end{array}$ \\
\hline PSD & $200 \mathrm{~g}$ & & & \\
\hline 4 & 60.23 & 60.23 & 30.115 & 30.115 \\
\hline 3 & 57.99 & 118.22 & 28.995 & 59.11 \\
\hline 2 & 11.79 & 130.01 & 5.895 & 65.005 \\
\hline 1 & 15.32 & 145.33 & 7.66 & 72.665 \\
\hline 0.5 & 12.60 & 157.93 & 6.3 & 78.965 \\
\hline 0.25 & 5.22 & 163.15 & 2.61 & 81.575 \\
\hline 0.16 & 3.48 & 166.63 & 1.74 & 83.315 \\
\hline 0.125 & 1.71 & 168.34 & 0.855 & 84.17 \\
\hline 0.063 & 2.97 & 171.31 & 1.485 & 85.655 \\
\hline Total & 171.31 & & 85.655 & \\
\hline
\end{tabular}

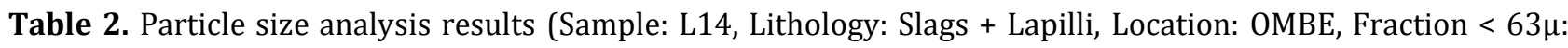
30,63, Dry start weight: 200g, Final dry weight: 169,37g)

\begin{tabular}{|l|l|l|l|l|}
\hline Mesh size of sieves (mm) & Partial refusals (g) & Cumulative refusals (g) & Partial percentages (\%) & $\begin{array}{l}\text { Cumulative percentages } \\
(\%)\end{array}$ \\
\hline PSD & 200 & & & \\
\hline 4 & 68.1 & 68.1 & 34.05 & 34.05 \\
\hline 3 & 33.55 & 101.65 & 16.775 & 50.825 \\
\hline 2 & 28.26 & 129.91 & 14.13 & 64.955 \\
\hline 1 & 19.13 & 14.04 & 9.565 & 74.52 \\
\hline 0.5 & 7.93 & 156.97 & 3.965 & 78.485 \\
\hline 0.25 & 5.18 & 162.15 & 2.59 & 81.075 \\
\hline 0.16 & 2.65 & 164.8 & 1.325 & 82.4 \\
\hline 0.125 & 1.51 & 166.31 & 0.755 & 83.155 \\
\hline 0.063 & 3.06 & 169.37 & 1.53 & 84.685 \\
\hline Total & 169.32 & & 84.66 & \\
\hline
\end{tabular}

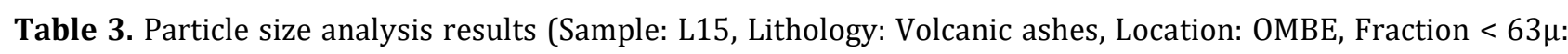
58.01, Dry start weight: $200 \mathrm{~g}$, Final dry weight: $141.99 \mathrm{~g}$ )

\begin{tabular}{|l|l|l|l|l|}
\hline Mesh size of sieves (mm) & Partial refusals (g) & Cumulative refusals (g) & Partial percentages (\%) & $\begin{array}{l}\text { Cumulative percentages } \\
(\%)\end{array}$ \\
\hline PSD & 200 & & & \\
\hline 4 & 14.05 & 14.05 & 7.025 & 7.025 \\
\hline 3 & 11.01 & 25.06 & 5.505 & 12.53 \\
\hline 2 & 15.96 & 41.02 & 7.98 & 20.51 \\
\hline 1 & 27.52 & 68.54 & 13.76 & 34.27 \\
\hline 0.5 & 27.86 & 96.4 & 13.93 & 48.2 \\
\hline 0.25 & 21.08 & 117.48 & 10.54 & 58.74 \\
\hline 0.16 & 9.09 & 126.57 & 4.545 & 63.285 \\
\hline 0.125 & 5.62 & 132.19 & 2.81 & 66.095 \\
\hline 0.063 & 9.8 & 141.99 & 4.9 & 70.995 \\
\hline Total & 141.99 & & 70.995 & \\
\hline
\end{tabular}

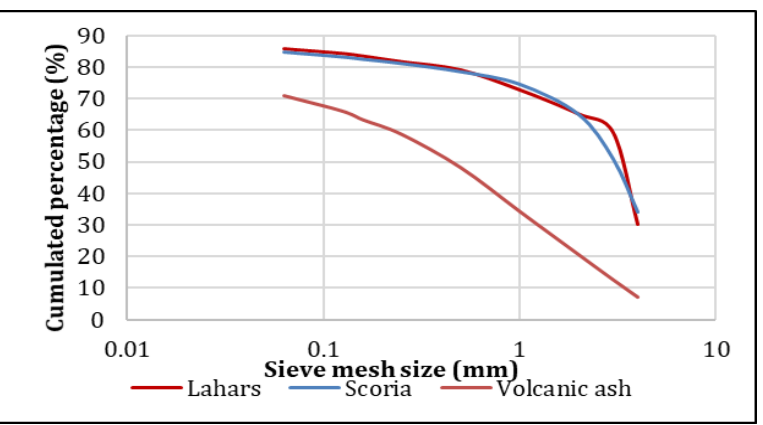

Figure 10. Particle size curves of lahars, scoria and volcanic ash of Mount Cameroon

\subsection{Economic Interest and Impact of Their Exploitation on the Environment}

Today, rocks are still the primary source of materials used by man for landscaping and major works. The development of the road network and the building boom in Cameroon require the opening of quarries near urban centers with high demand as Ombe. On the whole, quarries are opened in places where the material deposits are large and accessible. Their exploitation generates positive impacts (roads), and negative impacts (environment). 


\subsubsection{Prospecting of materials}

The size and distribution of the studied lahars are related to geomorphology. The materials follow pre-existing valleys and sometimes interlayered with alluvium, colluvium and various pyroclasts, as is the case in Ombe and mutengene in our study site. They are thin on steep slopes and upstream, but thick downstream. Research carries out on significant concentrations of exploitable material, specific locations:

In waterways, there are abundant and highly concentrated materials in meanders of the Ombe River where lahar materials are exploited by several companies.

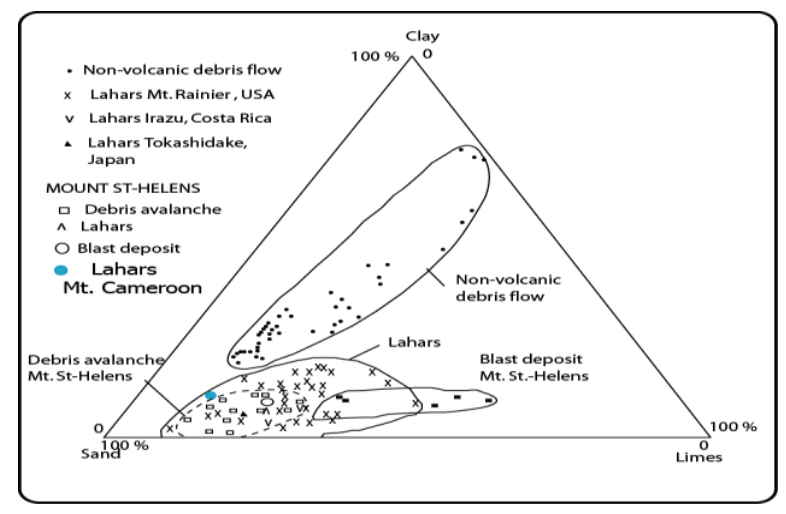

Figure 11. Position of Mount Cameroon lahars in the grain size distribution diagram of Lahars (Fisher and Schminke, 1984; Scott et al., 1995)

On slopes, the material is relatively less thick, but with a high concentration of large blocks ranging from $50 \mathrm{~cm}$ to $3 \mathrm{~m}$ in size at Dibanda and Tamben (especially upstream the Benoe River). Slope deposits are of a very good quality for deprived of fine particles, but steep slopes and difficult access hinder their exploitation.

In plains, the material is abundant in various sizes (fine to block) but scattered. Small size elements $(\leq 30 \mathrm{~cm})$ abound.

\subsubsection{Use, exploitation and environmental impact}

To produce aggregates for public works in general and road development in particular, several companies exploit Mount Cameroon lahars on the south-eastern flank. This open-cast exploitation affects the environment in various ways.

\subsubsection{In civil engineering}

Aggregates mainly used in road construction and others (bridges, houses,) with pozzuolanic properties can be used in the construction of treated subbases. The vesicular texture of materials is important. Their dry density is often relatively low, not leading to its rejection (due to their porosity). The optimal moisture content is insignificant (CEBTP, 1984).

\subsubsection{Exploitation}

Basalt blocks are mined in the open air (Figure 12a) preceded by stripping the plant cover and the overburden that masks the deposit. Boulders are carried to the crushing station for physical transformation to gravel of granulometry $0 / 31.5$, $15 / 25,10 / 15,5 / 10$ and $0 / 5 \mathrm{~mm}$. Besides is the large release rock dust. Aggregates are stored in heaps by granulometry (Figure 12b) and later loaded in trucks to various destinations.

\subsubsection{Environmental impacts}

The exploitation of quarries on Mount Cameroon lahars shows direct or indirect negative effects on the environment, the safety and health of local residents.

On the ground, clearing and earthwork during the opening of roads and the construction of structures expose the ground surface usually protected by vegetation to immediate erosion or compaction and sealing of surface layers. Leaking oil, grease and fuel from machines pollute the soil. This leads to the loss of productivity, destabilization of nature, reduction of agricultural land and shaping of topography.

On water resources: during extraction rivers become pasty due to enormous fine load or mud (Kuété, 1999). The water once drinkable and consumed by the populations becomes unusable. Some villages in the area change their water supply, but not the Ombe populations.

On air quality: extraction activities are a corollary of deterioration in air quality through the emission of fumes from machinery and trucks, dust and siliceous particles. This is a danger to the health of the workers and the populations of the surrounding villages.

Vegetation: as long as there are quarries, the regeneration of plants becomes difficult. Thick layers of dust particles on the vegetation hinder their growth. Siliceous dust particles cover the leaves of plants many kilometers round the site.

On wildlife: wild animals are no longer found in the area driven away by the noise of the machinery, the crushing of blocks and the destruction of their habitat.

\subsection{Agricultural Interest of Soils Developed on Lahars}

The soil provides plants with mineral nutrients that are absorbed by the roots. On the south-eastern flank of Mount Cameroon, soils developed on lahars show an abundant plant cover and high mineral reserves due to the proximity of the parent rock. They very well suit food crops, banana, cocoa and coffee, oil palm and rubber (Figure 13a and 13b). 


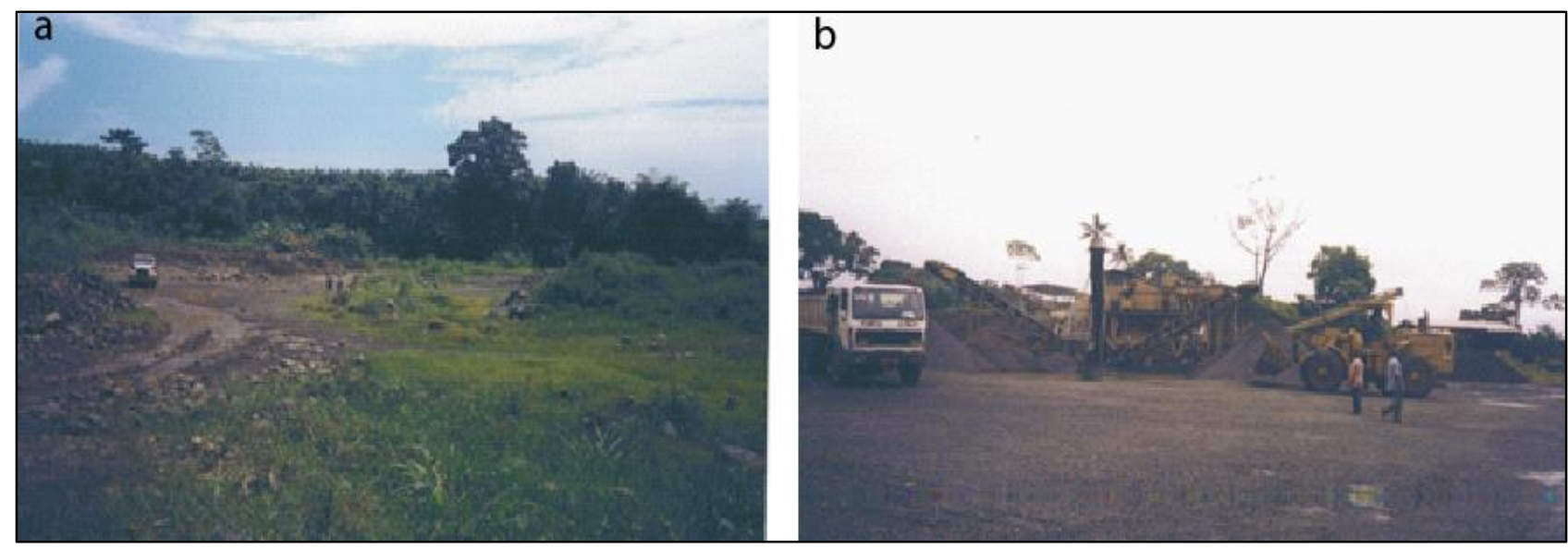

Figure 12. a) Exploitation of lahar blocks. b) Crushing and storage of aggregates
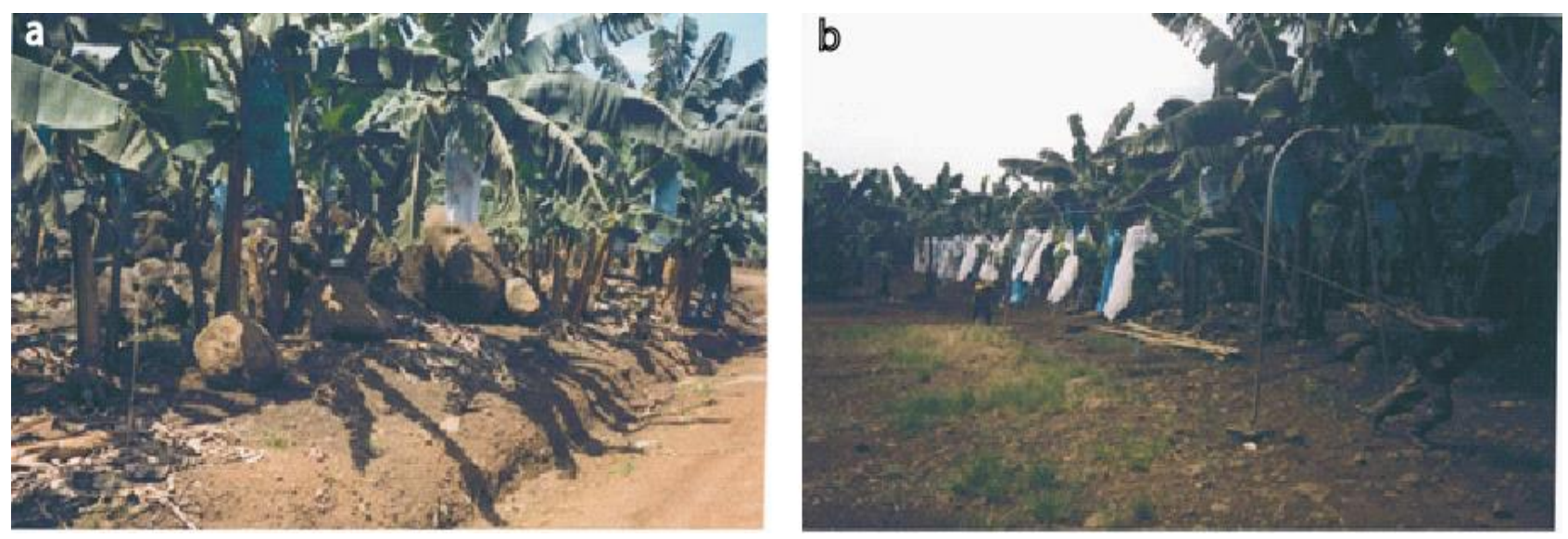

Figure 13. Agricultural interest of lahars: a) fertile lahars soils in agro-industry; b) Industrial banana plantations

\section{DISCUSSION}

\subsection{Interpretation of the Lahars}

The studied lahars present large polygenic blocks of various sizes. Slopes of $50^{\circ}$ played a major role in setting them up. Blocks covered nearly $25,000 \mathrm{~m}$ in the valleys at high speed as far as the Tiko plain. An enormous quantity of water also favored the formation of lahars from rain or ice. The distribution of rainfall at Mount Cameroon varies according to flanks (Figure 14). The SW flank shows the most rainfall but no lahars. But the SE flank shows average rainfall and thick and widespread lahars. Thus, rainfall is not the trigger factor for lahars. For their glacial origin Déruelle (1982) and Zogning (1988) describe two possibilities. Lahars result from soliflution flows related to periglacial freeze-thaw or sub-glacial eruption phenomena. Tricart and Cailleux (1965) and Maley (1983) suggest very important Quaternary climatic oscillations in Africa. Thick layers of ice covered some coastal regions (e.g. the Gulf of Guinea coast) during ice ages (Günz, Mindel, Riz and Würm) (Scaëtta, 1937; Moby Etia, 1979). For example, Kenya's glaciers descended to an altitude of $3300 \mathrm{~m}$. However, Mount Cameroon peak is at $4100 \mathrm{~m}$. In the end of Pleistocene between 20,000 and 15,000 years BP (at Würm) there was a strong phase of rapid erosion and sedimentation as shown by sediment analyses from Lake Barombi-Mbo near Mount Cameroon (Maley, 1996; Giresse et al., 1994). These erosions were probably melts from Pleistocene glaciers, explaining the origin of the water that generated the Mount Cameroon lahars, as in Nevada del Ruiz in Colombia (Thouret et al., 1995).

Mount Cameroon volcanism started in the Tertiary (Eocene) (Tsafack et al., 2009) by releasing basalts with Hawaiian to Strombolian dynamism. It continued in the Quaternary building hundreds Strombolian cones explained by the excellent conservation and freshness of rocks. For, these lahars comprise blocks of altered rock (probably of Tertiary age) and blocks of fresh rock, suggesting their formation in the Quaternary from the melting of glaciers, precisely in Pleistocene $(20,000-15,000$ years BP, würm) (Scaëtta, 1937). The size decrease of elements of lahar deposits on the SE slope result from a loss of water velocity (Lavigne and Thouret, 2000; Vallance and Iverson, 2015) leading to an abrupt stop of large elements. Fine elements settled farther (Figure 7). Thus, these are primary lahars of syn-eruptive type according to the classification of Lavigne (1998) resulting from a Strombolian dynamism during Quaternary glaciations. 


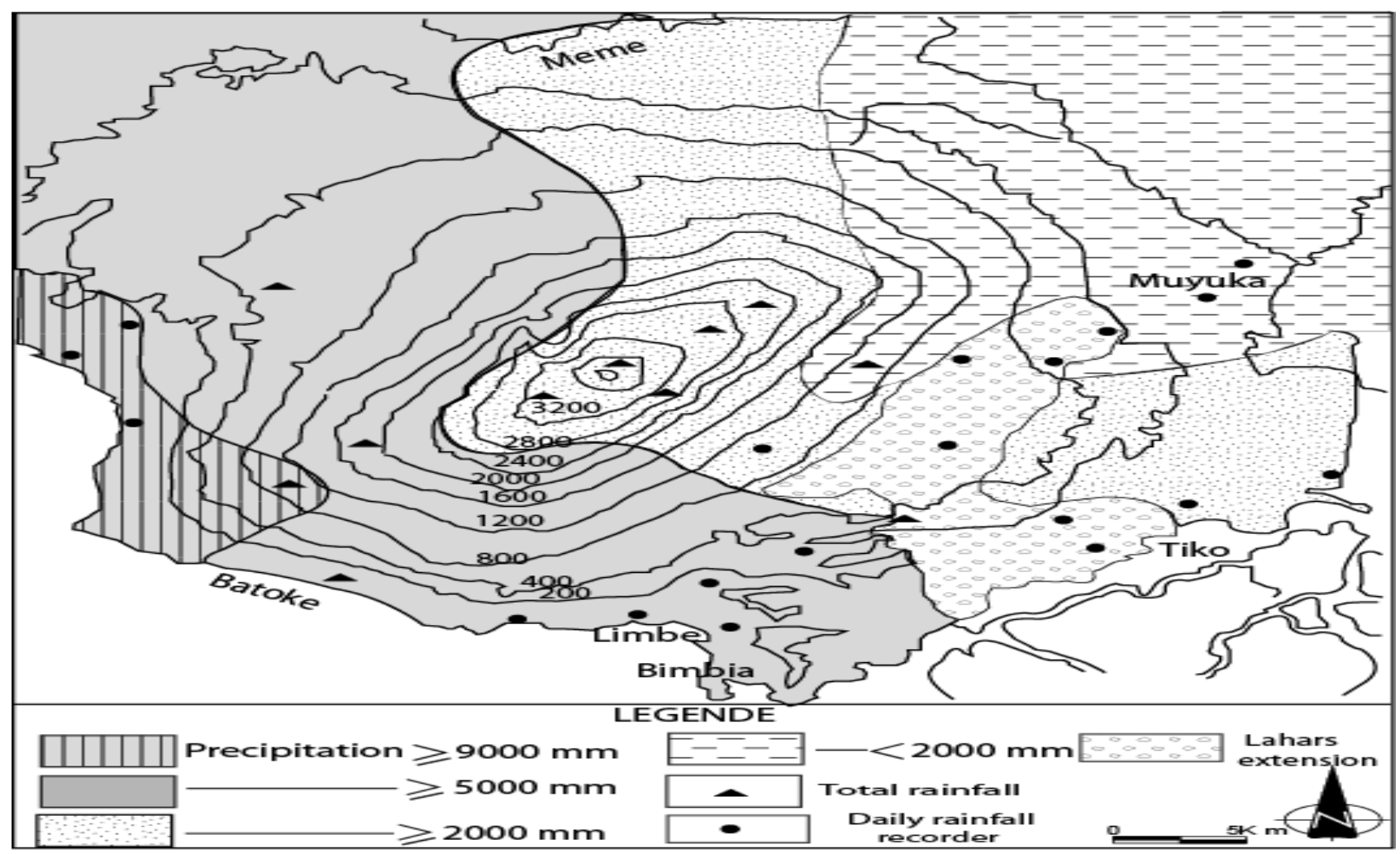

Figure 14. Distribution of rainfall and lahars on Mount Cameroon (Zogning, 1988)

\section{CONCLUSION}

Mount Cameroon lahars are deposits of large volumes of volcanic material that tumbled down the slopes of the volcano after eruptions. They are compact or vacuolar basalts in blocks of different sizes (centimeters to meters), pyroclasts (ash and slag) and carbonized wood. Rocks are aphyric or porphyritic with olivine, pyroxene or plagioclase phenocrysts.

Besides climatic factors, other parameters that influenced the release mobility and the setting up of lahars are slope, volume and thickness of remobilized deposits, nature and physico-hydraulic features of deposits. The material mostly in rivers (at meander bends) is exploited to produce aggregates for civil engineering. The exploitation affects the immediate environment, mainly the soil, vegetation, quality of water in rivers and health of the local population. Lahars soils are very fertile and suit for agriculture.

\section{Acknowledgement}

The authors would like to thank the Cameroon Geological and Mining Research Institute for all the facilities provided and also the Sedimentology Laboratory of the University of Yaoundé I for the granulometric analyses.

\section{Author Contributions}

Joseph Legrand Tchop: Collected the datasets and analyzed the data, Methodology, Validation. Victor
Metang: Investigation and data collection in the field. Jacques Dili-Rake: Making of figures Gaelle Vanessa Nana: Participation in field investigation. Pauline Wokwenmendam Nguet: Writing the manuscript-review and editing. Bernard Tassongwa: Writing the manuscript-review and editing. Benjamin Ntieche: Reviewing the manuscript before submission.

\section{Conflicts of Interest}

The authors declare no conflict of interest.

\section{REFERENCES}

Ateba, B., Dorbath, C., Dorbath, L., Ntepe, N., Frogneux, M., Akja, F.T., Hell, J.V., Delmond, J.C., \& Manguelle, D. (2009). Eruptive and earthquake activities related to the 2000 eruption of Mount Cameroon volcano (West Africa). Journal of Volcanology and Geothermal Research, 179, 206-216.

Ateba, B., \& Ntepe, N. (1997). Post-eruptive seismic activity of Mount Cameroon (Cameroon, West Africa): A statistical analysis. Journal of Volcanology and Geothermal Research 79 (1-2), 25-45.

Ayonghe, S.N., Suh, C.E., Ntasin, E.B., Samalang, P., \& Fantong, W. (2002). Hydrologically, seismically and tectonically triggered landslides along the Cameroon Volcanic Line, Cameroon. Africa Geosciences Review, 9(4), 325-336. 
Ayonghe, S.N., Ntasin, E.B., Samalang, P., \& Suh, C.E. (2004). The June 27, 2001 landslide on volcanic cones in Limbe, Mount Cameroon, West Africa. Journal of Africa Earth Science 39(3-5), 435439.

Bardintzeff, J.M., Déruelles, B., Cheminée, J.L., Etame, J., Fosso, J., Hell, J.V., Lissom, J., Ngounouno, I., Nkouathio, D.G., Nkoumbou, C., Nni, J., \& Nono, A. (2000). L'éruption de mars-avril 1999 du Mont Cameroun: dynamisme et premières données pétrologiques. Cahier géologique, 135, 1835-1837.

Dionne, J.C. (1991). Campy, M et Macaire, JJ (1989), Géologie des formations superficielles (Géodynamique-faciès-utilisation). Géographie physique et Quaternaire, 45(1), 118-119.

CEBTP, (1984). Guide pratique de dimensionnement des chaussées des pays tropicaux. Ministère de la coopération de la République Française (Eds).155 p.

Corwin, K.A., Brand, B.D., Hubbard, M.L., \& Johnston, D.M. (2017). Household preparedness motivation in lahar hazard zones: assessing the adoption of preparedness behaviors among laypeople and response professionals in communities downstream from Mount Baker and Glacier Peak (USA) volcanoes. Journal of Applied Volcanology, 6(1), 1-19.

Déruelle, B. (1982). Risque volcanique au Mont Cameroun. Revue de Géographie du Cameroun, 3(1). 33-40.

Déruelle, B., N’ni, J., \& Kambou, R. (1987). Mont Cameroon: an active volcano of the Cameroon Line. Journal of Africa Earth Sciences, 6(2), 197214.

Déruelle, B., Moreau, C., Nkoumbou, C., Kambou, R., Lissom, J., Njonfang, E., ... \& Nono, A. (1991). The Cameroon line: a review. Magmatism in extensional structural settings, 274-327.

Fisher R.V., \& Schemincke H.U. (1984). Pyroclastic Rocks, Springer-verlag. Berlin, Heidelberg, New York, Tokyo, 472.

Fitton, J.G. (1987). The Cameroon line, West Africa: a comparison between oceanic and continental alkaline volcanism. Geological Society, London, Special Publications, 30(1), 273-291.

Giresse, P., Maley, J., \& Brenac, P. (1994). Late Quaternary palaeoenvironments in the Lake Barombi Mbo (West Cameroon) deduced from pollen and carbon isotopes of organic matter. Palaeogeography, Palaeoecology, 107(1-2), 65-78.
Huguet, D., Thouret, J.C., Nehlig, P., Raffy, J., \& Rochette, P. (2001). Les lahars du strato-volcan du Cantal (Massif Central, France): stratigraphie, modes de mise en place et implication paléo-géomorphologiques. Bulletin de la Société Géologie de France, 172(5), 573585.

Kagou Dongmo, A., Wandji, P., Pouclet, A., Vicat, J.P., Cheilletz, A., Nkouathio D.G., \& Tchoua, F.M. (2001). Évolution volcanologique du mont Manengouba (Ligne du Cameroun); nouvelles données pétrographiques, géochimiques. géochronologiques. Comptes Rendus Academie des Sciences-Series IIA-Earth and Planetary Science. 333(3), 155-162.

Kervyn, M.B. Van Wyk de Vries, B., Walter, T.R., Njome, M.S., Suh, C.E., \& Ernst, G.G.J. (2014). Directional flank spreading at Mount Cameroon volcano: Evidence from analogue modeling, Journal of Geophysic. Research. Solid Earth, $119(10), 7542-7563$.

Kretz, R. (1983). Symbols for rock-forming minerals. American mineralogist, 68(1-2), 277279.

Kuété, M. (1999). Exploitation des ressources naturelles dans les environs de Dschang: Impact environnemental. Géosciences au Cameroun, JP Vicat et P. Bilong, ed., Collection Géocam, 47-54.

Lambi, C.M., \& Nwana, B.S. (1991). Human interference and environmental instability: the case of the Limbe landslide. Revue de géographie du Cameroun, 10(1), 44-52.

Lavigne, F., \& Thouret, J.C. (2000). Les lahars; depots, origines et dynamique. Bulletin de la Société géologique de France, 171(5), 545-557.

Lavigne, F. (1998). Les lahars du volcan Merapi, Java central, Indonésie (Doctoral dissertation, Clermont-Ferrand 2).

Lavigne, F., Thouret, J.C., Voight, B., Suwa, H., \& Sumaryono, A. (2000). Lahars at Merapi volcano, Central Java: an overview. Journal of volcanology and geothermal research, 100(1-4), 423-456.

Maley, J. (1983). Histoire de la végétation et du climat de l'Afrique nord-tropicale au Quaternaire récent. Bothalia, 14(3/4), 377-389.

Moby Etia, P. (1979). Climats. In les Atlas Jeune Afrique, République Unie du Cameroun. 
N'NI, J. (1984). Le volcan actif du mont Cameroun (ligne du Cameroun): géologie et pétrologie du volcan (Doctoral dissertation).

Ngounouno, I., Déruelle, B., Montigny, R., \& Demaiffe, D. (2006). Les camptonites du mont Cameroun, Cameroun, Afrique. Comptes Rendus Geoscience, 338(8), 537-544.

Ngwa, C.N., Lenhardt, N., Le Roux, P., \& Mbassa, B.J. (2019). The subsurface magma eruptions: Geochemical constraints on the subsurface magma plumbing system. Journal of Volcanology and Geothermal Research, 384, 179-188.

Nkoumbou, C., Nana, R., Eno Belinga, S., Vicat, J.P., \& Tchoua, F. (2001). Les éruptions du Mont Cameroun de 1999: Etude volcanologique. Histoire Géologique du Cameroun. Eno Bélinga 117-123.

Rodolfo, K.S., \& Arguden, A.T. (1991). Rain-Lahars generation and sediment-delivery system at Mayon volcano.

Scaëtta, H. (1937). Variations du climat pléistocène en Afrique Centrale. In Annales de Géographie, 46(260), 164-171.

Scott, K.M., Vallance, J.W., \& Pringle, P.T. (1995). Sedimentology, behavior and hazard of debris flows at Mount Rainier, Washington, US Geological Survey, 1547, 56.

Smith, G.A., \& Fritz, W.J. (1989). Volcanic influences on terrestrial sedimentation. Geology, 17(4), 375-376.

Suh, C.E., Ayonghe, S.N., Sparks, R.S. J., Annen, C., Fitton, J.G., Nana, R., \& Luckman, A. (2003). The 1999 and 2000 eruptions of Mount Cameroon: eruption behaviour and petrochemistry of lava. Bulletin of Volcanology, 65(4), 267-281.

Tchungouelieu, H.W., Pizette, P., Wouatong, A.S.L., Abriak, N.E., Borrel, L.R., Razafimahatratra, N.F., Ngapgue, \& F, Guouillier, T. (2018). Effect of $0 / 5$ basaltic aggregates on geotechnical properties of fine lateritic soils from Bafang (West-Cameroon) for road construction purposes. National Geotechnical and Engineering Geology Days.

Thouret, J.C., Abdurachman, K.E., Bourdier, J.L., \& Bronto, S. (1998). Origin, characteristics, and behaviour of subsequent lahars of the 1990 eruption at Kelud, East Java (Indonesia). Bulletin of Volcanology, 59, 460-480.

Thouret, J.C., Vandemeulebrouck, J., Komorowsky, J. C., \& Valla, F. (1995). Volcano-glacier interactions: field survey, remote sensing and modelling-a case study Nevado del Ruiz, Colombia. Steepland geomorphology, Sleymaker 0., 63-88.

Tricart, J., \& Cailleux, A. (1965). Introduction à la géomorphologie climatique (Vol. 1). Société d'édition d'enseignement supérieur.

Tsafack, J.P.F., Wandji, P., Bardintzeff, J.M., Bellon, H., \& Guillou, H. (2009). The Mount Cameroon stratovolcano (Cameroon volcanic line, Central Africa): petrology, geochemistry, isotope and age data. Geochemistry, mineralogy and Petrology, 47, 65-78.

Tsalefac, M., Ngoufo, R., Nkwambi, W., Tatsangue, E. D., \& Fobissie, B.L. (2003). Fréquences et quantités des précipitations journalières sur le territoire camerounais. Publ. AIC, 15, 359-367.

Tytgat Nele, J.L. (2008). Susceptibility analysis of the risk of small landslides on the southern slope of Mount Cameroon Volcano. Unpublished MSc thesis, Ghent University.

Vallance, J.W., \& Iverson, R.M. (2015). Lahars and their deposits. In The encyclopedia of volcanoes (649-664). Academic Press.

Vallance, J.W., \& Scott, K.M. (1997). The Osceola Mudflow from Mount Rainier: Sedimentology and hazard implications of a huge clay-rich debris flow. Geological Society of America Bulletin, 109(2), 143-163.

Wandji, P., Tsafack, J.P.F., Bardintzeff, J.M., Nkouathio, D.G., Dongmo, A.K., Bellon, H., \& Guillou, H. (2009). Xenoliths of dunites, wehrlites and clinopyroxenites in the basanites from Batoke volcanic cone (Mount Cameroon, Central Africa): petrogenetic implications. Mineralogy and Petrology, 96(1-2), 81-98.

Zogning, A. (1988). Le Mont Cameroun, un volcan actif: contribution à l'étude de géographie physique appliquée (Doctoral dissertation, unpublished doctoral thesis, University of Yaounde, Cameroon). 